\title{
Pengaruh Konsumsi Pir (Pyrus) terhadap Indeks Debris pada Siswa SD Garuda di Kota Manado
}

\author{
Tanindy M. Sipayung \\ Paulina N. Gunawan \\ Johanna A. Khoman \\ Program Studi Pendidikan Dokter Gigi Fakultas Kedokteran \\ Universitas Sam Ratulangi Manado \\ Email: msnindy96@gmail.com
}

\begin{abstract}
Oral hygiene is part of body health that can not be separated one from another. One of the oral diseases that commonly occurs among children is dental caries. The influencing factor that causes caries is debris or food residue around the teeth. Mastication of fibrous food like pear could clean the teeth. Pear fruit is rich of nutritive materials which are able to block the growth of Streptococcus mutans on the formed teeth and to enhance bacterial protein denaturation. This study was aimed to obtain the effect of pear consumption on debris index in children aged 9 years at Garuda elementary school in Manado. This was a quasi-experimental study with a pre and post-test design. Population was all of the students aged 9 years at Garuda elementary school in Manado. There were 48 students as samples obtained by using total sampling method. The results showed that the average difference of debris index value in the experimental group was 1.04 and in the control group was 0.34 . The Mann-Whitney test obtained a $P$ value of $0.000(<0.05)$ that indicated significant differences between the former and the later debris index in the experimental group and the control group. Conclusion: Pear consumption could influence the debris index in children aged 9 years at Garuda elementary school in Manado.
\end{abstract}

Keywords: pear, debris index

\begin{abstract}
Abstrak: Kesehatan gigi dan mulut merupakan bagian dari kesehatan tubuh yang tidak dapat dipisahkan sebab kesehatan gigi dan mulut memengaruhi kesehatan tubuh. Salah satu penyakit mulut yang paling sering terjadi pada anak ialah karies gigi. Faktor pendukung penyebab terjadinya karies gigi yaitu debris atau sisa makanan yang terdapat di sekitar gigi. Mengunyah makanan berserat seperti buah pir dapat membantu membersihkan gigi. Buah pir kaya akan zat gizi yang mampu menghambat bakteri Streptococcus mutans pada pembentukan gigi serta mendenaturasi protein sel bakteri. Penelitian ini bertujuan untuk mengetahui pengaruh konsumsi buah pir (Pyrus) terhadap indeks debris pada anak usia 9 tahun di SD Garuda Manado. Jenis penelitian ialah eksperimental semu dengan pre and posttest design. Populasi penelitian yaitu seluruh siswa SD Garuda Manado yang berusia 9 tahun. Pengambilan sampel dilakukan dengan metode total sampling yang berjumlah 48 sampel. Hasil penelitian pada kelompok eksperimen mendapatkan nilai selisih rerata indeks debris sebesar 1,04 dan pada kelompok kontrol nilai selisih rerata indeks debris sebesar 0,34. Uji Mann-Whitney mendapatkan nilai $P=0,000(<0,05)$ yang menunjukkan bahwa terdapat perbedaan bermakna antara selisih indeks debris awal dan akhir pada kelompok eksperimen dibandingkan kelompok kontrol. Simpulan: Terdapat pengaruh konsumsi buah pir (Pyrus) terhadap indeks debris pada anak usia 9 tahun di SD Garuda Manado.
\end{abstract}

Kata kunci: buah pir, indeks debris 
Kesehatan gigi dan mulut merupakan bagian dari kesehatan tubuh yang tidak dapat dipisahkan satu dengan yang lainnya sebab kesehatan gigi dan mulut akan memengaruhi kesehatan tubuh. ${ }^{1}$ Salah satu penyakit mulut yang paling sering terjadi pada anak ialah karies gigi. ${ }^{2}$ Karies merupakan suatu penyakit pada jaringan keras gigi yang merusak struktur email, dentin dan sementum. Penyebab karies yaitu adanya aktivitas jasad renik (mikroorganisme jenis laktobasilus) yang melakukan proses peragian pada plak di permukaan gigi. Proses peragian ini menghasilkan suatu kondisi asam pada permukaan email yang mengakibatkan terjadinya karies. ${ }^{3}$

Faktor pendukung lainnya yang menyebabkan terjadinya karies gigi yaitu debris atau sisa-sisa makanan yang terdapat di sekitar gigi. Debris adalah material lunak yang terdapat pada permukaan gigi terdiri dari lapisan biofilm, material alba, dan sisa makanan. Debris mempunyai pengaruh yang cukup besar terhadap proses terjadinya karies. Luas permukaan debris dapat diukur dengan indeks debris. Indeks debris adalah skor debris yang menempel pada permukaan gigi penentu. Pengukuran indeks debris dilakukan untuk mengukur permukaan gigi yang ditutupi oleh debris. ${ }^{4}$

Karies gigi umumnya banyak ditemukan pada anak usia sekolah karena pada usia tersebut anak sudah lebih aktif untuk menentukan apa yang dimakan dan kapan mau mengonsumsinya. ${ }^{5}$ Cokelat, permen, atau biskuit-biskuit manis merupakan makanan yang sangat disukai anak-anak pada umumnya. Makanan ini mengandung banyak gula dan biasa memunculkan berbagai gangguan kesehatan gigi dan mulut. ${ }^{5}$ Konsumsi buah dan sayuran segar yang kaya akan vitamin, mineral, serat, dan air dapat melancarkan pembersihan sendiri pada gigi, sehingga luas permukaan plak dan debris dapat dikurangi dan pada akhirnya karies gigi dapat dicegah. Buahbuahan segar seperti bengkoang, pir, semangka serta sayuran seperti caisim dan wortel dapat merangsang fungsi pengunyahan dan meningkatkan sekresi saliva. ${ }^{6}$

Mengunyah makanan berserat seperti buah-buahan dapat membantu membersihkan gigi. Buah pir kaya akan zat gizi, serta berkhasiat sebagai antikanker dan antibakteri. Selain rasanya yang manis dan banyak dijumpai di sekitar kita, buah pir juga merupakan buah segar yang umumnya disukai masyarakat dengan harga terjangkau. Buah pir juga mengandung senyawa katekin yang mampu menghambat perlekatan bakteri Streptococcus mutans pada pembentukan gigi serta mendenaturasi protein sel bakteri sehingga bakteri tersebut mati. $^{7}$

Adanya ketertarikan masyarakat untuk mengonsumsi buah-buahan menyebabkan supermarket yang berada di Sulawesi Utara tepatnya di Manado menyediakan produk buah, baik buah lokal maupun buah impor. Pada supermarket tersebut terdapat berbagai jenis buah lokal seperti pisang, jeruk, sirsak, advokat dan lain-lain sedangkan buah-buahan impor seperti buah anggur, pir, kiwi, dan sawo. ${ }^{8}$

Penelitian ini bertujuan untuk mengetahui pengaruh konsumsi pir (Pyrus) dalam menurunkan indeks debris pada anak usia 9 tahun di SD Garuda Manado. Alasan peneliti memilih buah pir sebagai bahan penelitian karena buah ini mudah didapat serta banyak orang yang menyukai rasa buah pir. Pemilihan anak usia 9 tahun karena usia ini merupakan usia yang kritis terhadap terjadinya karies gigi dan juga mempunyai sifat khusus yaitu transisi gigi susu ke gigi permanen. Di SD Garuda belum pernah dilakukan penelitian mengenai indeks debris.

\section{BAHAN DAN METODE PENELITIAN}

Jenis penelitian ini ialah eksperimental semu (quasi experimental) dengan pre and post-test design. Penelitian dilakukan pada bulan Mei 2018 di SD Garuda Manado. Populasi penelitian ialah seluruh siswa SD Garuda Manado yang berusia 9 tahun. Dengan menggunakan total sampling berdasarkan kriteria inklusi dan ekslusi yang telah ditetapkan, diperoleh sampel sebesar 48 siswa yang terdiri dari 24 kelompok eksperimen dan 24 kelompok kontrol. Penelitian dilakukan setelah 
mendapat izin dari pihak sekolah dan adanya surat persetujuan informed consent yang telah ditandatangani oleh orang tua subjek penelitian.

Pengambilan data dilakukan dengan pemeriksaan intraoral untuk mengukur indeks debris dengan menggunakan cara perhitungan dari Green dan Vermillion sebagai berikut:

- Nilai 0: tidak ada debris atau stain

- Nilai 1: terdapat debris lunak menutupi tidak lebih sepertiga permukaan gigi.

- Nilai 2: terdapat debris lunak menutupi lebih dari sepertiga permukaan gigi, tetapi tidak lebih dari dua pertiga permukaan gigi.

- Nilai 3: terdapat debris lunak menutupi lebih dari dua pertiga permukaan gigi.

Skor indeks debris diperoleh dengan cara menjumlahkan debris skor tiap permukaan gigi dibagi dengan jumlah gigi yang diperiksa. Kriteria indeks debris sebagai berikut: baik $(0,0-0,6)$, sedang $(0,7-1,8)$, dan buruk (1,9-3,0).

Alat dan bahan yang digunakan dalam penelitian ini ialah kaca mulut, sonde, nierbeken, tissue, kapas, alkohol, masker, sarung tangan, lembaran informed consent, kartu indeks, alat tulis, timbangan makanan, pir jenis Shandong, dan coklat.

Penelitian ini menggunakan dua kelompok subyek yang berbeda dengan karakteristik yang sama, Kelompok eksperimen dan kelompok kontrol yang pertama diberi makan biskuit seberat 50 gram dan dikunyah sebanyak 32 kali. Setelah 3 menit diukur indeks debris yang pertama. Kemudian kelompok eksperimen yang pertama diberi makan buah pir 0 gram dan dikunyah sebanyak 32 kali, sedangkan kelompok kontrol tidak diberi perlakuan. Setelah kelompok eksperimen selesai mengunyah buah pir, 5 menit kemudian kelompok eksperimen dan kelompok kontrol diukur indeks debris yang kedua. Selanjutnya dilakukan hal yang sama pada kelompok eksperimen dan kelompok kontrol yang berikutnya.

Data yang terkumpul dianalisis dengan analisis univariat dan analisis bivariat. Penelitian ini menggunakan uji t-test tidak berpasangan untuk membandingkan antara kelompok perlakuan yang mendapat intervensi dan kelompok kontrol atau pembanding menggunakan bantuan SPSS dengan skala berbentuk rasio dan interval. Bila data tidak terdistribusi normal maka digunakan uji Mann-Whitney.

\section{HASIL PENELITIAN}

Distribusi karakteristik subyek penelitian berdasarkan jenis kelamin menunjukkan 17 subyek $(35,42 \%)$ berjenis kelamin perempuan dan 31 subyek (64,58\%) berjenis kelamin laki-laki (Tabel 1).

Tabel 1. Distribusi karakteristik sampel berdasarkan jenis kelamin

\begin{tabular}{ccc}
\hline Jenis kelamin & $\mathbf{N}$ & $\mathbf{\%}$ \\
\hline Perempuan & 17 & 35,42 \\
Laki-laki & 31 & 64,58 \\
Total & 48 & 100 \\
\hline
\end{tabular}

Hasil pemeriksaan indeks debris pada kelompok eksperimen dan kontrol berdasarkan kategori dibagi atas baik, sedang, dan buruk (Tabel 2) sedangkan rerata indeks debris pada kelompok eksperimen dan kontrol dapat dilihat pada Tabel 3.

Uji perbedaan indeks debris kelompok eksperimen dibandingkan kelompok kontrol melalui perbedaan nilai selisih indeks debris sebelum dan sesudah perlakuan pada kelompok eksperimen dan kontrol. Dalam penelitian ini digunakan uji Mann-Whitney dengan nilai signifikansi 0,000 $(P<0,05)$, yang menunjukkan terdapat perbedaan bermakna antara selisih indeks debris awal dan akhir pada kelompok eksperimen dengan kelompok kontrol. Dengan demikian dapat disimpulkan terdapat pengaruh konsumsi pir terhadap indeks debris pada anak usia 9 tahun di SD Garuda Manado. 
Sipayung, Gunawan, Khoman: Pengaruh konsumsi pir (Pyrus) terhadap ...

Tabel 2. Hasil pemeriksaan indeks debris pada kelompok eksperimen dan kontrol berdasarkan kategori

\begin{tabular}{ccccc}
\hline & \multicolumn{4}{c}{ Kelompok subyek } \\
\cline { 2 - 5 } Kategori & \multicolumn{2}{c}{ Eksperimen } & \multicolumn{2}{c}{ Kontrol } \\
\cline { 2 - 5 } & Sebelum & Sesudah & Sebelum & Sesudah \\
& Perlakuan & Perlakuan & Perlakuan & Perlakuan \\
\hline Baik & 0 & 11 & 0 & 0 \\
Sedang & 9 & 13 & 10 & 16 \\
Buruk & 15 & 0 & 14 & 8 \\
Total & 24 & 24 & 24 & 24 \\
\hline
\end{tabular}

Tabel 3. Rerata indeks debris pada kelompok eksperimen dan control

\begin{tabular}{lccc}
\hline \multirow{2}{*}{ Kelompok } & \multicolumn{3}{c}{ Rerata Indeks Debris } \\
\cline { 2 - 4 } & $\begin{array}{c}\text { Sebelum } \\
\text { perlakuan }\end{array}$ & $\begin{array}{c}\text { Sesudah } \\
\text { perlakuan }\end{array}$ & Selisih \\
\hline Eksperimen & 1,96 & 0,92 & 1,04 \\
Kontrol & 1,94 & 1,60 & 0,34 \\
\hline
\end{tabular}

\section{BAHASAN}

Berdasarkan hasil penelitian ini diketahui bahwa jumlah sampel dalam penelitian ini berjumlah 48 siswa. Berdasarkan jenis kelamin, laki-laki lebih banyak yaitu 31 siswa $(64,58 \%)$ dibandingkan dengan yang berjenis kelamin perempuan yang berjumlah 17 siswa $(35,42 \%)$ (Tabel 1).

Berdasarkan kategori indeks debris pada kelompok eksperimen sebelum perlakuan terdapat 9 siswa dengan kategori sedang, dan 15 siswa dengan kategori buruk, sedangkan indeks debris pada kelompok eksperimen sesudah perlakuan menjadi 11 siswa dengan kategori baik dan 13 siswa dengan kategori sedang (Tabel 2). Rerata nilai indeks debris pada kelompok eksperimen sebelum perlakuan sebesar 1,96 dan rerata nilai indeks debris pada kelompok eksperimen sesudah perlakuan 0,92 (Tabel 3). Dari data tersebut terlihat penurunan nilai indeks debris setelah perlakuan pada kelompok eksperimen yang juga menunjukkan bahwa kebersihan gigi dari subjek penelitian mengalami peningkatan. Faktor yang menyebabkan terjadinya peningkatan kebersihan gigi setelah mengunyah buah pir yaitu kandungan serat dalam buah pir.
Serat adalah polisakarida nonpati, yaitu karbohidrat kompleks yang terbentuk dari gugusan gula sederhana yang bergabung menjadi satu serta tidak dapat dicerna. ${ }^{9}$ Makanan padat dan berserat secara fisiologik akan meningkatkan intensitas pengunyahan dalam mulut. Proses pengunyahan makanan ini akan merangsang dan meningkatkan produksi saliva. Saliva akan membantu membilas gigi dari partikelpartikel makanan yang melekat pada gigi dan juga melarutkan komponen gula dari sisa makanan yang terperangkap dalam sela-sela pit dan fisur permukaan gigi. ${ }^{10}$

Berdasarkan kategori indeks debris pada kelompok kontrol sebelum perlakuan terdapat 10 siswa dengan kategori sedang, dan 14 siswa dengan kategori buruk, sedangkan indeks debris pada kelompok kontrol sesudah perlakuan, 16 siswa dengan kategori sedang, dan 8 siswa dengan kategori buruk (Tabel 2). Rerata indeks debris pada kelompok kontrol sebelum perlakuan sebesar 1,94 dan rerata nilai indeks debris pada kelompok kontrol sesudah perlakuan sebesar 1,60 (Tabel 3). Berdasarkan hal ini terlihat bahwa pada kelompok kontrol juga mengalami penurunan indeks debris tetapi penurunannya 
lebih rendah dibanding pada kelompok eksperimen. Hal ini terjadi karena pada kelompok kontrol tidak diberi perlakuan mengunyah buah pir, tetapi setelah mengunyah coklat diberi jeda waktu 5 menit sebelum dilakukan pemeriksaan yang kedua. Padahal mengonsumsi buah berserat merupakan salah satu cara mencegah terjadinya penumpukan sisa-sisa makanan pada permukaan atau sela-sela gigi. ${ }^{11}$ Oleh karena itu jeda waktu yang diberikan pada kelompok kontrol kurang efektif sehingga tidak dapat menghasilkan perubahan yang bermakna.

Rerata selisih indeks debris pada kelompok eksperimen sebesar 1,04 dan pada kelompok kontrol 0,34. Berdasarkan uji Mann-Whitney nilai probabilitas signifikansi $P=0,000(P<0,05)$, yang artinya terdapat perbedaan bermakna antara selisih indeks debris awal dan akhir pada kelompok eksperimen dengan kelompok kontrol. Hal ini menunjukkan terdapat pengaruh konsumsi pir terhadap indeks debris pada anak usia 9 tahun di SD Garuda Manado.

Hasil penelitian ini selaras dengan enelitian yang dilakukan oleh Mukti ${ }^{11}$ di Panti Asuhan Yayasan Nur Hidayah Surakarta yang menunjukkan adanya selisih penurunan indeks debris sebelum dan sesudah mengonsumsi buah berserat. Hasil penelitian ini juga mendukung pernyataan Hidayanti et al. ${ }^{12}$ yang menyebutkan bahwa konsumsi buah-buahan segar yang kaya serat dan air dapat melancarkan pembersihan sendiri pada gigi atau sering disebut self cleansing, sehingga luas permukaan debris dapat dikurangi serta plak dan karies gigi dapat dicegah. ${ }^{2}$ Hal ini juga dipaparkan pada penelitian yang dilakukan oleh Angela $^{13}$ tentang pencegahan primer pada anak yang berisiko karies tinggi bahwa memperbanyak makan sayur-sayuran dan buah-buahan yang berserat dan berair akan bersifat membersihkan dan merangsang sekresi saliva sehingga karies gigi dapat dicegah. Hal ini sejalan dengan penelitian yang dilakukan oleh Chemiawan et al. ${ }^{14}$ mengenai makanan yang banyak mengandung serat dan air yang berarti sedikit mengandung karbohidrat. Serat dapat memperlambat proses makan dan meningkatkan intensitas pengunyahan. Proses mengunyah makanan berserat akan merangsang saliva. ${ }^{14}$

Berdasarkan hasil uji Mann-Whitney diperoleh angka signifikansi yaitu 0,000 yang menunjukkan terdapat perbedaan bermakna antara selisih indeks debris awal dan akhir pada kelompok eksperimen dengan kelompok kontrol.

\section{SIMPULAN}

Berdasarkan hasil penelitian ini dapat disimpulkan bahwa konsumsi pir (Pyrus) dapat memengaruhi indeks debris pada anak usia 9 tahun di SD Garuda Manado.

\section{SARAN}

Disarankan agar pemerintah lebih menggiatkan program penyuluhan tentang kesehatan gigi dan mulut serta manfaat mengonsumsi sayur-sayuran dan buahbuahan khususnya buah pir terhadap kebersihan gigi.

Disarankan pada masyarakat agar dapat mengonsumsi sayur-sayuran dan buah-buahan yang berserat seperti pir untuk membantu mencegah proses terjadinya karies gigi.

Bagi pihak sekolah agar menganjurkan para siswa untuk mengonsumsi buahbuahan seperti pir setelah makan.

\section{DAFTAR PUSTAKA}

1. Nurhamidah, Ramadhan ES, Asmawati, Juni. Hubungan status kesehatan gigi dan mulut dengan prestasi belajar siswa/i SD Negeri 2 Sangga Beru Kecamatan Gunung Meriah Kabupaten Aceh Singkil. Jurnal Kesehatan Gigi. 2016;3(2):36-7.

2. Pratiwi R, Mutmainnah R. Gambar keparahan karies pada anak usia 6,9 dan 12 tahun di Kabupaten Pinrang, Sulawesi Selatan menggunakan indeks PUFA/ pufa. Dentofasial. 2013;12(2):76.

3. Kantja I. Pengaruh pola makan pada anak sekolah dasar terhadap status kesehatan gigi dan mulut [Skripsi]. Makassar: FKG Universitas Hasanuddin; 2015.

4. Lusnarnera R. Pengaruh konsumsi semangka (Citrullus lanatus) dalam menurunkan 
indeks debris pada anak usia 8-10 tahun. eG. 2016;4(1):54.

5. Lestari SP, Atmadi TA. Hubungan antara kebiasaan konsumsi makanan manis dengan karies gigi anak usia sekolah. Jurnal PDGI. 2016;65(2):56.

6. Hidayanti L, Lina N, Bachtiar KR. Peran buah dan sayur dalam menurunkan keparahan karies gigi pada anak [Skripsi]. Tasikmalaya: Universitas Siliwangi; 2008.

7. Ajeng RR. Pengaruh pengunyahan buah pir (Pyrus communis L) terhadap penurunan plak pada pemakaian alat orthodontic lepasan. Jurnal Kesehatan Gigi. 2010;4(3):3.

8. Lomboan RH. Tingkat kepuasan konsumen buah local dan buah impor terhadap pelayanan di pasar swalayan di Kota Manado. Cocos. 2014;3(2):4.

9. Yulandris S. Hubungan tingkat pengetahuan dengan tingkat konsumsi buah dan sayur pada anak kelas IV-V SD Pertiwi 3 [Skripsi]. Padang; Universitas Andalas; 2013.
10. Panda PAC, Kaligis SHM. Perbedaan indeks plak sebelum dan sesudah pengunyahan buah pir. eG. 2015;3(2): 381.

11. Pratiwi AI. Manfaat berkumur sari buah delima merah (Punica granatum) terhadap penurunan plak gigi [Skripsi]. Denpasar: FKG Universitas Mahasaraswati; 2014.

12. Hidayanti L, Lina N, Bachtiar KR. Peran buah dan sayur dalam menurunkan keparahan karies gigi pada anak. eG. 2016;4(2):49.

13. Angela A. Pencegahan primer pada anak yang berisiko karies tinggi [Skripsi]. Medan: Departemen Pedodonsia FKG Universitas Sumatera Utara; 2005.

14. Chemiawan E, Riyanti E, Fransisca F. Perbedaan tingkat kebersihan gigi dan mulut antara anak vegetarian dan non vegetarian di Vihara Maitreya Pusat Jakarta [Skripsi]. Bandung: Departemen Pediatri FKG Universitas Padjadjaran; 2016. 